\title{
PENERAPAN PEMBELAJARAN QUANTUM TEACHING \\ PADA MATERI AKU DAN LINGKUNGANKU DALAM PENDIDIKAN \\ AGAMA BUDDHA UNTUK MENINGKATKAN KEAKTIFAN \\ DAN PEMAHAMAN KONSEP MATERI \\ SISWA KELAS XI SMK MPU TANTULAR BANYUMAS
}

\author{
Sutrisno $^{1}$, Hariyanto ${ }^{2}$, Prihadi Dwi Hatmono ${ }^{3}$ \\ Sekolah Tinggi Agama Buddha Negeri Raden Wijaya Wonogiri - Jawa Tengah \\ sutrisno.unno@gmail.com
}

\begin{abstract}
ABSTRAK
Keaktifan siswa dan pemahaman konsep terhadap materi menjadi kendala bagi siswa kelas XI SMK Mpu Tantular Banyumas. Permasalahan ini disebabkan oleh pembelajaran yang diterapkan masih monoton. Tujuan penelitian ini yaitu untuk mengetahui penerapan pembelajaran Quantum Teaching dapat meningkatkan keaktifan dan pemahaman konsep siswa kelas XI SMK Mpu Tantular Banyumas pada materi "aku dan lingkunganku". Penelitian ini merupakan penelitian tindakan kelas model Kurt Lewin. Instrumen yang digunakan berupa lembar observasi, pedoman wawancara, tes pemahaman konsep. Data kuantitatif dianalisis dengan deskriptif komparatif dan data kualitatif dianalisis dengan teknik analisis kritis. Hasil penelitian menunjukkan nilai rata-rata keaktifan siswa meningkat dari 43,2; siklus pertama menjadi 56; dan siklus kedua menjadi 79,74. Nilai rata-rata pemahaman konsep materi meningkat dari 64,46; siklus pertama menjadi 75,56; dan siklus kedua menjadi 84,46. Berdasarkan hasil penelitian, disimpulkan bahwa penerapan pembelajaran Quantum Teaching meningkatkan keaktifan siswa. Pemahaman konsep siswa meningkat dalam memahami konsep-konsep materi ajar.
\end{abstract}

Kata kunci : Pembelajaran Quantum Teaching, Keaktifan Siswa, Pemahaman Konsep Materi.

\begin{abstract}
The student activeness and understanding material concepts being problem for students at XI grade Mpu Tantular Senior High School at Banyumas. This problem is caused by learning which is still monoton model. The aim of this research is to improve the students activeness and understanding to material concepts of XI students grade in Mpu Tantular Senior High School at Banyumas on Aku dan Lingkunganku (Me and My Environment) Material. This research is a classroom action research with Kurt Lewin model. Instrumensts used are observation sheet, interview guidelines, and concepts understanding test. Quantitative data were analyzed with descriptive comparative and qualitative data were analyzed trough a critical analysis.The research result shows that average value of students activeness increased from 43,2 ; in first cycles, grows to 56; then increasing to be 79,74 in second cycles . The average value of the concept understanding increased from 64,46; in first cycles, students got 75,56; then incresing to be 84,46 in second cycles. Based on the research results, concluded that application of Quantum Teaching learning can improve the students activity. The understanding concept of students increase in understanding material concepts.
\end{abstract}

Keywords : Quantum Teaching Learning, Students Activeness, Material Concepts Understanding. 


\section{PENDAHULUAN}

Proses pembelajaran merupakan hal yang penting bagi kemajuan berpikir siswa. Proses pembelajaran berkaitan dengan metode atau pendekatan yang digunakan. Pendekatan pembalajaran digunakan sebagai cara untuk meningkatkan keefektifan kegiatan belajar. Menurut Grinder dalam Silberman (2013: p.28) menyatakan bahwa dari setiap 30 siswa, 22 diantaranya rata-rata dapat belajar secara efektif selama gurunya menghadirkan kegiatan-kegiatan belajar yang berkombinasi antara visual, auditori, dan kinestik. Namun, 8 siswa sisanya harus berusaha keras untuk memahami pelajaran bila tidak ada kecermatan dalam menyajikan pelajaran sesuai dengan cara yang siswa sukai.

Suatu pendekatan belajar yang baik harus memuat tiga aspek yaitu aspek kognitif, aspek afektif, dan aspek psikomotor. Salah satu indikator dari aspek kognitif adalah pemahaman (comprehension). Pemahaman mencakup kemampuan menangkap pengertian, menterjemahkan, dan menafsirkan (Hanafih, dkk. 2012: p.21). Pendekatan yang menekankan pada kemajuan berpikir siswa dapat membawa ke pemahaman siswa pada materi pembelajaran, sehingga siswa dapat menguasai konsep dari materi. Pembelajaran yang kurang menyenangkan dan membosankan membuat siswa kurang mampu melatih kemampuan dalam pemahaman konsep. Pemahaman konsep merupakan hal yang penting dalam pembelajaran Pendidikan Agama Buddha. Karena dengan pemahaman konsep akan memudahkan siswa dalam mempelajari Agama Buddha dan membentuk pola pikir yang mampu memecahkan permasalahan.
Berdasarkan wawancara dengan guru pendidikan agama Buddha yang dilakukan pada tanggal 11 Januari 2016 di SMK Mpu Tantular Banyumas, pembelajaran berlangsung hanya satu arah yaitu guru menjelaskan dan siswa mendengarkan. Pembelajaran ini disebut pembelajaran metode ceramah. Metode ceramah yang dilakukan di sekolah tersebut, merupakan metode yang umum digunakan dalam pembelajaran. Guru tersebut juga memberikan informasi bahwa siswa kelas XI merupakan siswa yang pendiam dan kurang aktif dalam pembelajaran. Kurang aktifnya siswa tersebut dilihat saat guru menerangkan hanya mendengarkan dan saat guru bertanya, siswa menjawab dengan singkat. Hal ini menyebabkan hanya seorang guru yang aktif dalam pembelajaran.

Hasil observasi keaktifan siswa pada pra siklus menunjukkan bahwa siswa masih kurang aktif dalam pembelajaran. Observasi yang dilakukan saat pembelajaran dengan tidak menerapkan pembelajaran Quantum Teaching, siswa masih berapa di kategori kurang aktif. Permasalahan yang timbul tidak hanya keaktifan, pemahaman konsep siswa terhadap materi masih berada di bawah KKM yang telah ditetapkan pihak sekolah yaitu 75. Pemahaman konsep siswa setelah dilakukan pre test masih berada di bawah kategori baik.

Permasalahan ini tidak sesuai dengan pendapat Slameto (2010: p.92) Bahwa salah satu syarat pelaksanaan pembelajaran yang efektif yaitu adanya belajar secara aktif, baik mental maupun fisik. Di dalam pembelajaran, siswa harus mengalami aktivitas mental, misalnya siswa dapat 
mengembangkan kemampuan intelektual, kemampuan berpikir kritis, kemampuan menganalisis, dan kemampuan mengucapkan pengetahuannya. Selain itu siswa mengalami aktivitas jasmani seperti mengerjakan sesuatu, menyusun intisari pelajaran, dan membuat peta.

Siswa yang kurang aktif cenderung akan terhambat dalam pemahaman konsep materi yang diajarkan. Berdasarkan keterangan yang diberikan guru pendidikan agama Buddha SMK Mpu Tantular Banyumas yang bernama Anung Purwati, siswa kurang memahami konsep dari materi "aku dan lingkunganku". Pembelajaran yang telah berlangsung pada tahun ajaran sebelumnya, siswa mengalami kesulitan dalam memahami konsep materi "aku dan lingkunganku". Materi ini bukan materi hafalan, sehingga perlu adanya pemahaman siswa terhadap materi tersebut.

Sebagaimana dikemukakan oleh Slameto (2010: p.151) mengenai perbandingan antara mahasiswa dengan siswa yang menempuh pendidikan di bawah jenjang perguruan tinggi, para mahasiswa memperluas pemahaman konsep dengan jalan membaca. Mereka dapat melakukan hal itu dengan mudah, karena dapat menerapkan banyak pengalaman tentang contoh-contoh konsep yang telah mereka kuasai pada bacaannya dan studinya sekarang. Tetapi siswa-siswa di jenjang sekolah sebelum perguruan tinggi, apabila mempelajari bahan pelajaran baru atau unit baru, umumnya belum mempunyai cukup pengalaman yang diperlukan, mereka juga belum mempunyai perbendaharaan terminologi dan konsep dasar yang cukup diperlukan untuk memperoleh konsep-konsep baru hanya dengan membaca dan mempelajari bahan-bahan tertulis.
Penggunaan pendekatan merupakan hal penting bagi input siswa dalam proses pembelajaran. Penggunaan metode ceramah yang biasa dilakukan oleh guru Pendidikan Agama Buddha adalah hal yang monoton. Kelemahan dari metode ini berada pada pengaitan antara ilmu yang dipelajari terhadap pengalaman pribadi siswa. Sehingga siswa kurang mampu mengembangkan konsep yang ada pada diri siswa. Hal ini dikarenakan siswa hanya mendengarkan dan menerima pelajaran yang didengar saja. Dampak negatif dari metode ini adalah siswa menjadi bosan, mengantuk, pasif, dan hanya mencatat (Slameto, 2010: p.65).

Berdasarkan permasalahan yang timbul dalam pembelajaran Pendidikan Agama Buddha di SMK Mpu Tantular Banyumas, maka diperlukan suatu bentuk pembelajaran yang menyenangkan untuk menyampaikan materi Pendidikan Agama Buddha secara efektif. Penerapan pendekatan pembelajaran yang tepat dapat mengurangi kejenuhan pada diri siswa dan dapat meningkatkan keaktifan serta pemahaman konsep siswa terhadap materi pembelajaran. Salah satu pendekatan pembelajaran yang diharapkan dapat meningkatkan keaktifan dan pemahaman konsep siswa pada materi "aku dan lingkunganku" adalah pembelajaran Quantum Teaching.

$$
\text { Pembelajaran Quantum Teaching }
$$
merupakan strategi untuk meningkatkan proses pembelajaran menjadi menyenangkan. Menurut DePorter, dkk (2010: 39) pembelajaran Quantum Teaching mencakup petunjuk untuk menciptakan lingkungan belajar yang efektif merancang pengajaran, menyampaikan isi, dan memudahkan proses pembelajaran. Pembelajaran ini mendorong siswa mengkontruksikan pengetahuan di benak 
siswa itu sendiri. Quantum Teaching memberikan langkah-langkah pembelajaran diharapkan dapat meningkatkan keaktifan dan pemahaman konsep siswa terutama pada materi "aku dan lingkunganku". Berdasarkan latar belakang masalah tersebut, peneliti tertarik untuk melakukan penelitian tindakan kelas dengan judul "Penerapan Pembelajaran Quantum Teaching pada Materi Aku dan Lingkunganku dalam Pendidikan Agama Buddha untuk Meningkatkan Keaktifan dan Pemahaman Konsep materi, Siswa Kelas XI SMK Mpu Tantular Banyumas”.

Masalah yang diteliti dalam penelitian ini antara lain:

1. Bagaimana penerapan pembelajaran Quantum Teaching untuk meningkatkan keaktifan siswa pada materi "aku dan lingkunganku"?

2. Bagaimana penerapan pembelajaran Quantum Teaching untuk meningkatkan pemahaman konsep siswa pada materi "aku dan lingkunganku"?

\section{METODE PENELITIAN}

\section{Jenis dan Desain Penelitian}

Penelitian ini menggunakan Penelitian Tindakan Kelas dengan Model Kurt Lewin. Model Kurt Lewin menjadi acuan pokok atau dasar dari adanya berbagai model penelitian PTK. Konsep pokok penelitian tindakan Model Kurt Lewin terdiri dari empat komponen, yaitu perencanaan (planning), tindakan (acting), pengamatan (observing), dan refleksi (reflecting) (Kusumah, W.,\& Dwitagama D., 2012: p.20).

\section{Tempat dan Waktu Penelitian}

Penelitian Tindakan Kelas ini dilakukan di SMK Mpu Tantular Banyumas Buntu
Kecamatan Kemranjen, Kabupaten Banyumas Jawa Tengah. Penelitian dilakukan selama 6 bulan yaitu Januari - Juni 2016.

\section{Subjek Penelitian}

Subjek dalam penelitian ini adalah siswa pendidikan Agama Buddha kelas XI SMK Mpu Tantular, Kecamatan Kemranjen, Kabupaten Banyumas, Propinsi Jawa Tengah dengan jumlah siswa 3.

\section{Teknik dan Insrumen Pengumpulan Data}

Penelitian ini menggunakan beberapa teknik pengumpulan data. Terdapat empat teknik yang diambil oleh peneliti yaitu:

a. Pengamatan/Observasi

Observasi dimaksudkan untuk melihat dan mengetahui keadaan pembelajaran pendidikan Agama Buddha dan keaktifan siswa kelas XI di SMK Mpu Tantular yakni sebelum dan sesudah penelitian dengan menggunakan pendekatan pembelajaran Quantum Teaching. Observasi untuk mengukur keaktifan siswa menggunakan skala Likert. Menurut Sugiyono (2015: p.134) skala Likert digunakan untuk mengukur sikap, pendapat, dan persepsi seseorang atau kelompok. Observasi untuk melihat keberhasilan pembelajaran Quantum Teaching menggunakan skala pengukuran dengan tipe skala Guttman dengan opsi "ya-tidak". Observasi dilakukan pada tanggal 17 Februari 2016, 26 Maret 2016 dan tanggal 30 Maret 2016.

b. Wawancara

$$
\text { Teknik ini digunakan untuk }
$$
mendapatkan informasi mengenai fakta dan 
informasi mengenai pelaksanaan pembelajaran Quantum Teaching. Wawancara dilakukan kepada dua subjek yaitu guru Pendidikan Agama Buddha dan siswa SMK Mpu Tantular Banyumas.

Tujuan wawancara pra siklus terhadap guru yaitu untuk memperoleh data awal berupa metode yang biasa dilakukan guru, tingkat pemahaman konsep siswa, tingkat keaktifan siswa, dan penerapan pembelajaran Quantum Teaching. Wawancara tersebut dilakukan pada tanggal 11 Januari 2016. Wawancara kedua yang dilakukan kepada guru setelah penerapan pembelajaran Quantum Teaching bertujuan untuk memperoleh informasi berkaitan dengan manfaat penerapan pembelajaran Quantum Teaching terhadap keaktifan siswa, pemahaman konsep materi siswa kelas XI dan kendala yang dialami guru saat melaksanakan pembelajaran tersebut. Wawancara tersebut dilakukan pada tanggal 31 Maret 2016.

Wawancara yang dilakukan siswa setelah dilaksanakan siklus I dan II yaitu tanggal 21 Maret 2016 dan 1 April 2016. Wawancara ini bertujuan untuk memperoleh informasi berkaitan dengan pembelajaran Quantum Teaching. Informasi tersebut berupa ketertarikan siswa terhadap pembelajaran Quantum Teaching, perbedaan pembelajaran Quantum Teaching dengan pembelajaran yang biasa diterapkan guru, pemahaman siswa terkait materi yang dijelaskan, dan kendala yang dialami siswa.

c. Tes

Tes ialah seperangkat rangsangan (stimuli) yang diberikan kepada seseorang dengan maksud untuk mendapatkan jawaban- jawaban yang dijadikan penetapan skor angka. Jenis tes yang digunakan dalam penetian ini adalah tes yang bertujuan untuk mengetahui pemahaman konsep. Instrumen tes ini dilakukan sesudah pelaksanaan siklus I yaitu tanggal 26 Maret 2016 dan setelah pelaksanaan siklus II yaitu tanggal 30 Maret 2016.

Instrumen pengumpulam data pada penelitian tindakan kelas ini yaitu:

a. Peneliti

Peneliti sebagai instrumen disebabkan karena seorang peneliti sebagai perencana, pelaksana pengumpul data, penganalisis, dan pada akhirnya menjadi pelopor hasil penelitiannya.

b. Lembar Observasi

Lembar observasi digunakan sebagai pedoman ketika melakukan pengamatan. Pedoman ini bertujuan untuk mempermudah mendapatkan data yang akurat. Instrumen ini guna mengetahui keberhasilan penerapan pembelajaran Quantum Teaching dan keaktifan siswa.

c. Pedoman Wawancara

Hal-hal yang tidak dapat diketahui melalui lembar observasi, peneliti menggunakan pedoman wawancara untuk mengetahui informasi yang lebih lanjut. Pedoman wawancara digunakan sebagai petunjuk wawancara yang dilakukan dengan siswa maupun guru. Isi dari pedoman wawancara ini berupa pertanyaan-pertanyaan yang diajukan untuk mendapatkan informasi mengenai penerapan pembelajaran Quantum Teaching. Selain itu, pedoman wawancara ini digunakan untuk mendapatkan informasi 
menganai hambatan yang ditemukan selama pembelajaran Quantum Teaching berlangsung.

d. Tes Tertulis

Tes tertulis yang dijadikan instrumen berbentuk pilihan ganda. Menurut Majid (2014: p.346) tes pilihan ganda dipakai untuk menguji penguasaan kompetensi pada tingkat berpikir rendah seperti pengetahuan (recall) dan pemahaman, sampai pada tingkat berpikir tinggi seperti aplikasi, analisis, sintesis, dan evaluasi. Tes yang digunakan pada penelitian ini merupakan tes dengan bentuk pilihan ganda. Jumlah soal tes untuk masing-masing siklus terdiri dari 15 butir soal. Penyusunan tes ini berpedoman pada standar kompetensi, kompetensi dasar, dan indikator pemahaman konsep yang telah ditentukan. Kisi-kisi instrumen tes pemahaman konsep dapat dilihat pada tabel dibawah ini.

\section{Validitas Instrumen}

Instrumen tes yang digunakan untuk mengukur pemahaman konsep siswa dalam penelitian ini menggunakan validitas isi. Validitas isi dilakukan oleh guru agama Buddha dengan membandingkan isi instrumen dengan silabus dan materi yang akan diajarkan. Guru terlebih dahulu meneliti silabus dengan standar kompetensi mengkontruksikan sikap umat Buddha terhadap lingkungan dengan materi "aku dan lingkunganku" dan membandingkan dengan isi tes pemahaman konsep yang telah disusun.

Validitas instrumen keaktifan siswa berupa observasi keaktifan siswa dilakukan dengan triangulasi teknik. Data yang dihasilkan dari lembar observasi dibandingkan dengan hasil wawancara dan foto saat penerapan pembelajaran
Quantum Teaching. Peneliti juga melakukan perbandingan data awal dengan data yang dihasilkan dari lembar observasi keaktifan siswa pada saat penerapan pembelajaran Quantum Teaching.

\section{Teknik Analisis Data}

Data kuantitatif dianalisis dengan teknik statistik deskriptif komparatif. Analisis tersebut adalah untuk menganalisis nilai siswa dalam pree test dan post test serta lembar observasi keaktifan siswa. Tes tersebut merupakan pengukuran terhadap pemahaman konsep siswa terhadap materi. Menurut Arikunto (2013: p.272) untuk dapat dicatat sebagai suatu prestasi belajar, guru mewajibkan untuk mengubah skor mentah yang diperoleh langsung menjadi skor berstandar 100 . Skor yang diperoleh siswa dihitung dengan rumus:

$\mathrm{N}=\frac{\text { Skor yang diperoleh }}{\text { Skor maksimal }} \times 100$

Rumus tersebut digunakan untuk menghitung nilai tes pemahaman konsep dan skor lembar observasi keaktifian siswa. Hasil dari perhitungan dengan menggunakan rumus tersebut kemudian dibagi dalam empat kategori skala (Suwandi, 2010: p.146)

\section{Tabel Kriteria Keberhasilan Pemahman Konsep}

\begin{tabular}{|l|l|}
\hline Nilai & Kategori \\
\hline $90-100$ & Baik sekali \\
\hline $80-89$ & Baik \\
\hline $70-79$ & Sedang \\
\hline$<70$ & Kurang Baik \\
\hline \multicolumn{2}{|l|}{ Sumber: Suwandi (2010: p.146) }
\end{tabular}

Nilai tes pemahaman konsep kemudian dicocokan dengan nilai Kriteria Ketuntasan Minimal (KKM) yaitu 75. Jika kurang dari 75 maka tidak tuntas. Persentase ketuntasan belajar siswa dari tes setiap 
akhir siklus diperoleh dengan rumus (Daryanto, 2011: p.192):

Persentase $=\frac{\sum \text { Siswa yang tuntas belajar }}{\sum \text { Seluruh Siswa }} \times 100 \%$

Keaktifan siswa yang telah diobservasi kemudian hasil dari observasi dibagi kedalam beberapa kategori. Kriteria keberhasilan keaktifan siswa dapat dibagi dalam lima kategori. Kategori ini berdasarkan kriteria penilaian yang dikemukakan oleh Suwandi (2010: p.130) yaitu:

\section{Tabel Kriteria Keberhasilan Keaktifan Siswa}

\begin{tabular}{|l|l|}
\hline Nilai & Kategori \\
\hline $90-100$ & Sangat Baik \\
\hline $70-89$ & Baik \\
\hline $50-69$ & Cukup \\
\hline $30-49$ & Kurang baik \\
\hline $10-29$ & Sangat Kurang Baik \\
\hline
\end{tabular}

Sumber: Suwandi (2010: p.130)

Nilai yang dihasilkan dari tes pemahaman konsep dan lembar observasi keaktifan siswa kemudian dicari rata-rata kelasnya dengan menggunakan rumus (Daryanto, 2011: p.191):

$$
\overline{\mathrm{X}}=\frac{\sum \mathrm{X}}{\sum \mathrm{N}}
$$

Keterangan: $\overline{\mathrm{X}}=$ Nilai Rata-rata

$$
\begin{aligned}
& \sum \mathrm{X}=\text { Jumlah Semua Nilai Siswa } \\
& \sum \mathrm{N}=\text { Jumlah Siswa }
\end{aligned}
$$

Data kualitatif dianalisis dengan teknik analisis kritis, yaitu mengidentifikasi kekurangan dan kelebihan pada saat penerapan pembelajaran Quantum Teaching.

\section{HASIL PENELITIAN DAN PEMBAHASAN}

\section{Deskripsi Data Kemampuan Siswa}

Deskripsi mengenai kemampuan awal siswa didapat dari hasil observasi pembelajaran yang dilakukan sebelum penerapan pembelajaran Quantum Teaching (pra siklus). Data awal siswa juga diperoleh dari hasil wawancara terhadap guru Pendidikan
Agama Buddha. Wawancara tersebut mengenai kemampuan siswa dalam memahami konsep materi Pendidikan Agama Buddha yaitu materi "aku dan lingkunganku" serta keaktifan siswa yang menjadi kendala dalam keberhasilan pembelajaran.

Pelaksanaan pembelajaran pra siklus dilaksanakan pada tanggal 17 Februari 2016. Pembelajaran pra siklus, siswa belum menunjukkan peran aktif dalam merespon pembelajaran. Pada saat guru menyampaikan materi, siswa hanya diam dan tidak memberikan respon. Begitu pula saat diberi kesempatan untuk bertanya, hanya satu siswa yang mengajukkan pertanyaan. Interktif sesama siswa saat pembelajaran belum muncul. Pembelajaran yang diterapkan belum mendorong siswa untuk berperan aktif dengan memberikan kesempatan kepada siswa untuk berani berpendapat di depan siswa lain. Berikut merupakan data nilai keaktifan siswa pada tahap pra siklus.

Tabel Hasil Observasi Keaktifan Siswa Pra Siklus

\begin{tabular}{|l|l|c|c|c|}
\hline \multirow{2}{*}{ No. } & \multicolumn{2}{|c|}{ Uraian } & \multicolumn{3}{|c|}{ Hasil } \\
\cline { 3 - 5 } & & Siswa A & Siswa B & Siswa C \\
\hline 1. & Skor Maksimal & 125 & 125 & 125 \\
\hline 2. & Skor Perolehan & 49 & 54 & 59 \\
\hline 3. & Nilai & 39,2 & 43,2 & 47,2 \\
\hline 4. & $\begin{array}{l}\text { Kategori Tingkat } \\
\text { Keberhasilan }\end{array}$ & Kurang & Kurang & Kurang \\
\hline 5. & Rata-rata Nilai & \multicolumn{3}{|c|}{43,2} \\
\hline
\end{tabular}

Berikut ini adalah hasil tes yang dilakukan sebelum diterapkannya pembelajaran Quantum Teaching. 
Tabel Hasil Tes Pra Siklus

\begin{tabular}{|l|l|l|l|l|c|}
\hline No. & Nama Siswa & L $/$ & Nilai & Kategori & Keterangan \\
\hline 1. & Siswa A & L & 60 & Kurang & Belum Tuntas \\
\hline 2. & Siswa B & P & 73,4 & Sedang & Belum Tuntas \\
\hline 3. & Siswa C & P & 60 & Kurang & Belum Tuntas \\
\hline \multicolumn{4}{|l}{ Rata-rata } & 64,46 \\
\hline
\end{tabular}

2. Deskripsi Hasil Penelitian Tindakan Kelas

Penelitian tindakan kelas ini dilaksanakan selama dua siklus. Setiap siklus terdiri dari 4 tahapan yaitu tahap perencanaan, tahap pelaksanaan tindakan, tahap observasi, dan tahap refleksi. Jika terdapat kekurangan dalam siklus I, maka akan dilaksanakan siklus 2 yang merupakan perbaikan dari siklus sebelumnya.

\section{Siklus I}

Tahap Perencanaan, peneliti bersama guru melakukan perencanaan sebagai berikut: (a) peneliti bersama guru menyamakan persepsi dan berdiskusi tentang pembelajaran materi "aku dan lingkunganku" dengan menerapkan pembelajaran Quantum Teaching; (b) menentukan waktu pelaksanaan penelitian siklus pertama; (c) menjelaskan rencana mengenai proses pembelajaran Quantum Teaching yang akan dilaksanakan pada penelitian tindakan kelas kepada guru pendidikan Agama Buddha agar tidak terjadi salah komunikasi; (d) membuat Rencana Pelaksanaan Pembelajaran (RPP) berpedoman pada tahapan pembelajaran Quantum Teaching. (e) menyusun instrumen penelitian dan dikonsultasikan atau divalidasi oleh guru.

Pelaksanaan tindakan dilaksanakan selama dua pertemuan. Pertemuan pertama dilaksanakan pada tanggal 2 Maret 2016.
Pelaksanaan tindakan dilaksanakan berdasarkan RPP siklus pertama dengan mengacu pada kerangka pembelajaran Quantum Teaching (TANDUR). Pada pertemuan ini, pertama adalah pembukaan pembelajaran dengan melafalkan paritta namakarapatha secara terpimpin. Guru menyampaikan tujuan pembelajaran dan kompetensi yang diharapkan. Selanjutnya guru memberikan motivasi kepada siswa untuk mengikuti materi yang akan disampaikan. Motivasi ini berupa gambaran awal kepada siswa tentang hal yang berkaitan dengan materi. Gambaran kasus pembalakan liar dapat mengakibatkan dampak buruk bagi kehidupan makhluk hidup maupun lingkungan sekitar. Setelah itu, guru mendorong siswa agar berpendapat mengenai kejadian pembalakan liar tersebut.

Kemudian guru menjelaskan materi mengenai ekosistem dan lingkungan. Pembelajaran berlangsung tidak jauh beda dengan pembelajaran yang diterapkan guru saat belum menggunakan pembelajaran Quantum Teaching. Siswa masih pasif dan hanya mendengarkan yang dijelaskan oleh guru tersebut. Sesuai dengan RPP yang telah dibuat, guru menugaskan siswa untuk menulis tentang upaya siswa dalam mencegah kerusakan lingkungan. Tugas tersebut ditulis diselembar kertas. Kemudian siswa disarankan untuk berdiskusi dengan siswa lain. Hal ini untuk meningkatkan keaktifan siswa. Setelah dikira cukup, satu persatu siswa maju ke depan kelas untuk mendemonstrasikan atas jawaban yang telah siswa tulis. Kemudian guru menyampaikan kesimpulan dari materi yang 
disampaikan. Pembelajaran berakhir dengan tepuk tangan bersama dan ditutup dengan pembacaan namakarapatha secara terpimpin.

Pertemuan kedua dari siklus satu dilaksanakan pada tanggal 16 Maret 2016. Kegiatan awal pembelajaran masih sama dengan pertemuan pertama. Sebelum guru menyampaikan materi, siswa menceritakan pengalaman dalam menjaga lingkungan sekitar dan siswa lain memberikan komentar. Kemudian guru menjelaskan materi. Siswa diberi tugas tentang alasan nyata dan akibat yang akan diterima jika siswa merusak lingkungan dan menuliskan materi yang telah diberikan. Siswa yang mengutarakan hasil diskusi tersebut diberikan tepuk tangan bersama. Selanjutnya guru membimbing siswa untuk menarik kesimpulan mengenai materi yang telah dibahas. Antusiasme siswa untuk memberikan kesimpulan materi terlihat jelas. Kesimpulan tersebut berisi pesan dan materi penting yang seharusnya dipahami oleh siswa. Pembelajaran tersebut ditutup dengan melafalkan namakarapatha secara terpimpin.

Hasil observasi keaktifan setiap siswa pada pembelajaran Quantum Teaching siklus pertama dilihat pada tabel berikut:

\section{Tabel Rekapitulasi Hasil Observasi Keaktifan}

Siswa Siklus I

\begin{tabular}{|l|l|c|c|c|}
\hline \multirow{2}{*}{ No. } & \multirow{2}{*}{ Uraian } & \multicolumn{3}{c|}{ Hasil } \\
\cline { 3 - 5 } & & Siswa A & Siswa B & Siswa C \\
\hline 1. & Skor Maksimal & 125 & 125 & 125 \\
\hline 2. & Skor Perolehan & 71 & 80 & 59 \\
\hline 3. & Nilai & 56,8 & 64 & 47,2 \\
\hline 4. & $\begin{array}{l}\text { Kategori Tingkat } \\
\text { Keberhasilan }\end{array}$ & Cukup & Cukup & $\begin{array}{c}\text { Kurang } \\
\text { baik }\end{array}$ \\
\hline Rata-rata Nilai & \multicolumn{4}{|c}{56} \\
\hline
\end{tabular}

Pembelajaran Quantum Teaching terdapat aspek yang tidak dilakukan oleh guru dalam melaksanakan pembelajaran Quantum Teaching. Terdapat 3 aspek yang tidak dilakukan oleh guru. Hal ini menjadi kendala atas peningkatan pemahaman konsep siswa terhadap materi pembelajaran dan keaktifan siswa dalam mengikuti pembelajaran.

Penilaian pemahaman konsep dengan menerapkan pembelajaran Quantum Teaching, dilakukan melalui tes tertulis dengan aspek pemahaman konsep terhadap materi "aku dan lingkunganku". Berikut ini adalah hasil tes pemahaman konsep masing-masing siswa.

Tabel Hasil Pemahaman Konsep Siklus I

\begin{tabular}{|l|l|l|l|l|}
\hline No. & \multicolumn{1}{|c|}{ Nama Siswa } & Nilai & Kategori & Keterangan \\
\hline 1. & Siswa A & 66,7 & Kurang & Belum Tuntas \\
\hline 2. & Siswa B & 80 & Baik & Tuntas \\
\hline 3. & Siswa C & 80 & Baik & Tuntas \\
\hline 4. & Rata-rata & 75,56 & \\
\hline 5. & Persentase Ketuntasan & $66,6 \%$ & \\
\hline
\end{tabular}

Berdasarkan wawancara yang telah dilakukan kepada salah satu siswa, pembelajaran Quantum Teaching cukup menarik. Siswa menyatakan pembelajaran tersebut dapat menambah pengetahuan tentang pelajaran agama Buddha yang berkaitan dengan hubungan timbal balik. Pembelajaran menjadi aktif dengan tanya jawab mengenai materi. Tetapi siswa belum memahami pertanyaan yang digunakan untuk mengukur pemahaman konsep siswa. Permasalahan ini terjadi karena siswa belum sepenuhnya memahami konsep materi yang diajarkan.

Refleksi terhadap keaktifan siswa, keaktifan siswa yang masih berada pada kategori cukup merupakan hal yang harus 
diperbaiki. Guru masih belum menguasai pembelajaran Quantum Teaching sehingga siswa belum dapat menunjukkan keaktifan yang diharapkan. Guru perlu menguasai pembelajaran Quantum Teaching dengan cara menerapkan RPP yang telah dibuat bersama. Sehingga guru tidak merasa bingung dalam penerapan pembelajaran Quantum Teaching. Sedangkan refleksi terhadap pemahaman konsep siswa, terdapat siswa yang masih belum memahami konsep dari materi secara maksimal. Hal ini dikarenakan siswa kurang tertarik saat pemberian kesan awal sebelum memasuki pembelajaran. Selain itu, siswa belum dikondisikan siap untuk menerima pembelajaran oleh guru. Kondisi tersebut dapat diatasi dengan guru memberikan kesan awal sebelum pembelajaran yang lebih menarik dan guru terlebih dahulu memerhatikan kondisi siswa sebelum masuk ke materi pembelajaran.

\section{Siklus II}

Tahap perencanaan siklus kedua merupakan perbaikan dari siklus pertama. Membuat suasana yang tidak seperti biasanya merupakan solusi bagi siswa yang merasa tidak terkesan dengan pembelajaran Quantum Teaching. Mengatur tempat duduk siswa agar dapat saling berinteraksi akan membuat suasana kelas yang berbeda. Selain hal tersebut, peneliti dan guru juga merencanakan agar siswa memahami konsep materi yang akan dibahas dengan memberikan kesempatan bagi siswa menceritakan kewajibannya kepada orangtua. Berbeda dengan siklus pertama pada awal pembelajaran siswa menceritakan kejadian yang belum tentu siswa alami. Pada siklus II, siswa menceritakan kejadian yang siswa lakukan sehari-hari sehingga kesan menarik untuk mengikuti pembelajaran akan muncul.

Pada pertemuan kedua, pembelajaran dirancang untuk memberikan variasi pada pembelajaran. Selain menumbuhkan rasa tertarik siswa, penggunaan media video juga akan menambah pemahaman siswa mengenai materi yang diajarkan. Keaktifan siswa, dalam kegiatan ini juga akan muncul. Siswa akan memberikan pendapat yang berbeda untuk merespon video tersebut. Penambahan media video pada pertemuan ini sesuai dengan prinsip pembelajaran Quantum Teaching bahwa segala dari lingkungan kelas hingga bahasa tubuh guru, dari kertas yang dibagikan guru hingga rancangan pembelajaran semuanya mengirim pesan tentang belajar. Selain itu, pembelajaran Quantum Teaching merupakan pembelajaran yng menarik. Sumber dan fasilitas yang terlibat dalam setiap pembelajaran pada prinsipnya untuk membantu perubahan kognitif, afektif, dan psikomotor.

Selain menyiapkan rencana pelaksanaan pembelajaran, peneliti dan guru pendidikan agama Buddha menyiapkan instrumen yang akan digunakan dalam siklus kedua. Instrumen tersebut berupa instrumen lembar observasi keaktifan siswa, observasi pembelajaran, dan tes pemahaman konsep. Tes pemahaman konsep terdiri dari pretest dan post test.

Pelaksanaan Tindakan dilakukan selama dua pertemuan. Pertemuan pertama dilaksanakan pada tanggal 23 Maret 2016. Pembukaan pembelajaran diawali dengan 
pembacaan Namakarapatha secara terpimpin oleh salah satu siswa. Guru mengecek kehadiran siswa pada hari tersebut. Sebelum pembelajaran dimulai, guru menginstruksikan siswa untuk mengatur kursi saling berhadapan dan membentuk setengah lingkaran kecil. Siswa menunjukkan peran sertanya dengan menceritakan pengalaman sehari-hari yang berkaitan dengan kewajiban orangtua.

Guru memberikan input berupa materi sejarah Sigalovada Sutta. Saat pembelajaran berlangsung siswa sudah aktif bertanya mengenai hal yang belum diketahui siswa. Berkaitan dengan materi, guru menanyakan kewajiban yang seharusnya dilakukan siswa pada masa ini. Pembelajaran berakhir dengan menyimpulkan materi yang telah disampaikan. Kesimpulan ini dibuat oleh siswa dengan dibantu guru pendidikan agama Buddha. Tepuk tangan bersama setelah pembelajaran diinstruksikan guru agar siswa menjadi semangat dan percaya diri. Kemudian siswa berseru "kita pasti bisa" dengan dipandu oleh guru. Pembelajaran diakhiri dengan memanjatkan Namakarapatha secara terpimpin oleh salah satu siswa.

Pertemuan kedua pada siklus II dilaksanakan pada tanggal 30 Maret 2016. Pertemuan ini sama seperti pertemuan pertama. Perbedaannya terletak pada penggunaan media video yang berkaitan dengan kewajiban anak terhadap orangtua. Kemudian siswa diberi tugas untuk menulis pesan yang tersirat dalam video tersebut. Beragam pesan disampaikan oleh siswa dihadapan siswa lain. Keaktifan siswa dan pemahaman konsep siswa terhadap materi aku dan lingkunganku sudah nampak secara merata.

Sebelum pembelajaran diakhiri, guru membimbing siswa untuk menyampaikan kesimpulan satu persatu. Siswa mengutarakan kesimpulan yang beragam. Kemudian guru menyimpulkan materi berdasarkan materi yang diajarkan dan kesimpulan yang disampaikan siswa. Guru memberikan apresiasi terhadap siswa berupa acungan jempol dan dilanjutkan tepuk tangan bersama. Pembelajaran diakhiri dengan melafalkan namakarapatha secara terpimpin.

Hasil dari tahap observasi keaktifan siswa pada siklus kedua yaitu:

\section{Tabel Rekapitulasi Hasil Keaktifan Siswa}

Siklus II

\begin{tabular}{|l|l|c|c|c|}
\hline \multirow{2}{*}{ No. } & \multirow{2}{*}{ Uraian } & \multicolumn{3}{c|}{ Hasil } \\
\cline { 3 - 5 } & & Siswa A & Siswa B & Siswa C \\
\hline 1. & Skor Maksimal & 125 & 125 & 125 \\
\hline 2. & Skor Perolehan & 96 & 102 & 101 \\
\hline 3. & Nilai & 76,8 & 81,6 & 80,8 \\
\hline 4. & $\begin{array}{l}\text { Kategori Tingkat } \\
\text { Keberhasilan }\end{array}$ & Baik & Baik & Baik \\
\hline 5. & Rata-rata Nilai & \multicolumn{3}{|c}{79,74} \\
\hline
\end{tabular}

Pembelajaran Quantum Teaching yang diterapkan pada siklus kedua dengan materi aku dan lingkunganku menunjukkan adanya perkembangan. Perkembangan tersebut adalah dilaksanakannya semua rencana pelaksanaan pembelajaran yang telah disusun peneliti dan guru pendidikan agama Buddha. Terlaksanakannya pembelajaran sesuai dengan RPP dapat meningkatkan keaktifan dan pemahaman konsep siswa terhadap materi yang telah diajarkan. Berikut ini merupakan hasil post test pemahaman konsep siklus kedua: 
Tabel Hasil Post Tes Siklus II

\begin{tabular}{|l|l|l|l|l|}
\hline No. & \multicolumn{1}{|c|}{ Nama Siswa } & Nilai & Kategori & \multicolumn{1}{|c|}{ Keterangan } \\
\hline 1. & Siswa A & 80 & Baik & Tuntas \\
\hline 2. & Siswa B & 86,7 & Baik & Tuntas \\
\hline 3. & Siswa C & 86,7 & Baik & Tuntas \\
\hline 4. & Rata-Rata Nilai & 84,46 & \\
\hline 5. & Persentase Ketuntasan & \multicolumn{3}{l}{} \\
\hline
\end{tabular}

Pembelajaran Quantum Teaching pada siklus ke dua dapat dilaksanakan dengan baik oleh guru. Peneliti mengadakan wawancara dengan guru pendidikan agama Buddha, beliau menyatakan bahwa pembelajaran Quantum teaching tepat dilaksanakan untuk meningkatan keaktifan siswa dan pemahaman konsep. Siswa telah lebih berani mengemukakan pendapat dan mengomentari pendapat siswa lain. Hasil tes pemahaman konsep siswapun dapat meningkat dengan optimal.

Peneliti melakukan wawancara kepada siswa setelah dilaksanakannya pembelajaran Quantum Teaching. Para siswa mengatakan pembelajaran tersebut menyenangkan berbeda dengan pembelajaran yang diterapkan oleh guru selama ini. Siswa juga bersemangat dalam merespon pembelajaran. Materi yang disampaikan jadi lebih dapat dipahami oleh siswa.

Refleksi terhadap keaktifan siswa dan pemahaman konsep dilakukan setelah pembelajaran siklus II selesai. Pembelajaran Quantum teaching telah dilakukan dengan baik oleh guru pendidikan agama Buddha. Guru telah berhasil melaksanakan pembelajaran sesuai dengan perencanaan sebelumnya. Perencanaan pembelajaran dirancang untuk meningkatkan pemahaman konsep dan keaktifan siswa. Sehingga siswa mampu menunjukkan keaktifan dalam pembelajaran.
Siswa sudah mulai terbiasa dengan menanggapi situasi pembelajaran. Rasa malu untuk bertanya siswa sudah tidak ada. Siswa juga mampu mengoptimalkan sumber bacaan yang telah diberikan guru.

Berdasarkan observasi dan tes pemahaman konsep yang telah dilaksanakan pada siklus kedua, siswa telah mampu menunjukkan kemajuan dalam pemahaman konsep terhadap materi yang disampaikan. Siswa dengan percaya diri mengerjakan tes pemahaman konsep. Pembelajaran yang berjalan dengan baik memberikan hasil yang optimal terhadap nilai pemahaman konsep siswa.

\section{PEMBAHASAN}

\section{Penerapan Pembelajaran Quantum}

Teaching untuk Meningkatkan Keaktifan Siswa.

Berdasarkan analisis data yang diperoleh peneliti melalui penelitian tindakan kelas ini, dapat diketahui terdapat peningkatan keaktifan siswa dalam pembelajaran Quantum Teaching. Keaktifan siswa meningkat setelah guru menerapkan pembelajaran Quantum Teaching. Peningkatan keaktifan siswa ditunjukkan dengan adanya peningkatan nilai keaktifan siswa yang diperoleh dari data observasi keaktifan siswa. Data keaktifan siswa tersebut diperoleh pada pra siklus, siklus pertama, dan siklus kedua.

Penelitian ini menunjukkan adanya dampak positif penerapan pembelajaran Quantum Teaching terhadap keaktifan siswa. Hal ini dilihat dari hasil observasi pada pra siklus dengan nilai siswa A 39,2; siswa B 43,2; 
siswa C 47,2. Pada siklus pertama keaktifan siswa mengalami peningkatan tetapi belum semua siswa yaitu siswa A 56,8; siswa B 64 ; siswa C 47,2. Tidak optimalnya peningkatan keaktifan siswa pada siklus pertama disebabkan belum munculnya pengakuan atas partisipasi siswa. Pada siklus kedua keaktifan siswa meningkat dengan kategori baik yaitu siswa A 76,8; siswa B 81,6, dan siswa C 80,8. Berdasarkan nilai observasi tersebut, pada siklus pertama keaktifan siswa meningkat sebesar $66,6 \%$ dengan jumlah siswa 2 sedangkan pada siklus kedua, keaktifan siswa meningkat dengan kategori baik berjumlah 3 siswa yaitu $100 \%$. Berikut ini adalah diagram peningkatan keaktifan siswa.

\section{Gambar Nilai Keaktifan Siswa}

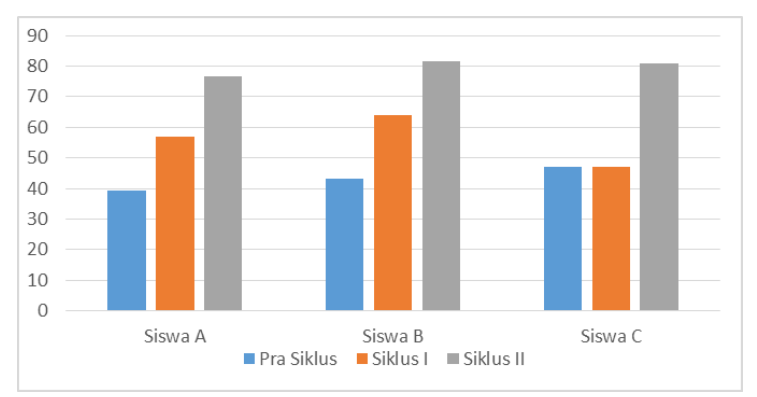

Meningkatnya keaktifan siswa relevan dengan teori yang dikemukakan oleh DePorter dalam Sa'ud (2012: p.128) mengenai pembelajaran Quantum Teaching bahwa pembelajaran tersebut memiliki beberapa prinsip, salah satunya pengalaman pemberian nama. Teori ini diperkuat oleh Majid (2014: p.12) bahwa pembelajaran melalui pengalaman merupakan pembelajaran yang berpusat pada siswa dan berorientasi pada aktivitas siswa. Penekanan terhadap pengalaman terdapat pada proses pembelajaran dan bukan hasil belajar. Jadi segala aktivitas siswa dalam belajar menjadi tujuan yang penting. Demikian pula dengan pembelajaran Quantum Teaching yang diterapkan oleh peneliti dan guru pendidikan agama Buddha dapat meningkatkan aktivitas siswa yang berupa keaktifan dalam pembelajaran.

\section{Penerapan Pembelajaran Quantum}

\section{Teaching untuk Meningkatkan Pemahaman} Konsep Siswa.

Berdasarkan hasil tes yang telah dilaksanakan, siswa mengalami peningkatan dalam memahami konsep materi. Perubahan tersebut diukur dengan melihat data pemahaman konsep siswa sebelum penerapan pembelajaran Quantum Teaching dan data hasil tes pemahaman konsep siswa setelah penerapan pembelajaran Quantum Teaching. Peningkatan pemahaman konsep terhadap materi ajar siswa kelas XI SMK Mpu Tantular telah mencapai kriteria ketuntasan minimum (KKM) yaitu 75 dan termasuk dalam kategori baik. Berikut ini adalah diagram peningkatan pemahaman konsep terhadap materi aku dan lingkunganku dari data awal siswa sampai siklus II.

\section{Gambar Nilai Pemahaman Konsep}

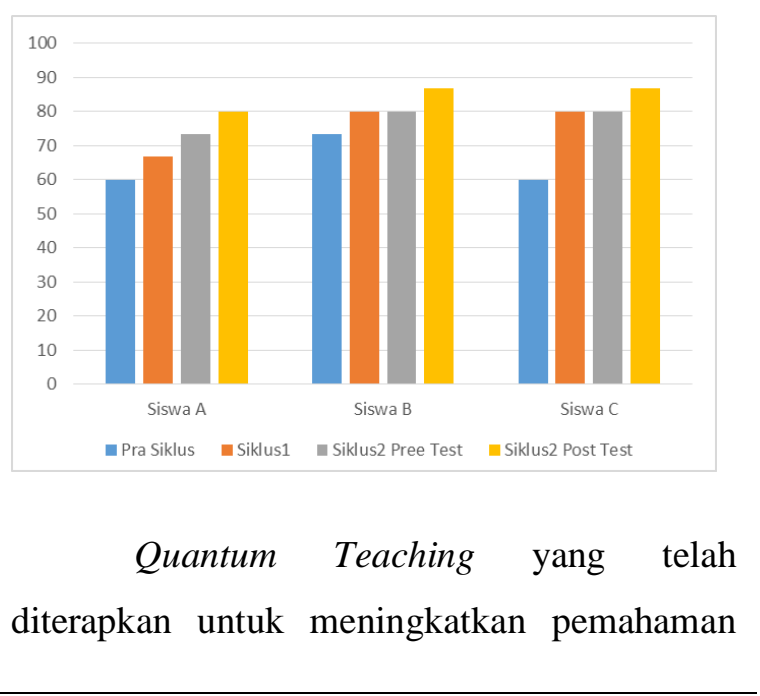


konsep terbukti berhasil. Hasil ini sesuai dengan teori yang dikemukakan oleh Majid, (2014: p.331) bahwa Quantum Teaching memiliki kerangka perancangan atau langkahlangkah pembelajaran kuantum. Kerangka tersebut menjamin siswa mengalami pembelajaran, berlatih, memahami isi pembelajaran, dan mencapai sukses. Rata-rata nilai yang telah diakumulasikan menjadi indikator naiknya pemahaman konsep siswa. Data awal pemahaman konsep siswa pada pra siklus sebesar 64,46, pada siklus I naik menjadi 75,56, dan siklus II mengalami peningkatan menjadi 84,46.

\section{SIMPULAN}

Berdasarkan data hasil penelitian tindakan kelas dan pembahasan, dapat disimpulkan bahwa penerapan pembelajaran Quantum Teaching pada materi aku dan lingkunganku dalam pendidikan agama Buddha dapat meningkatkan keaktifan dan pemahaman konsep materi, siswa kelas XI SMK Mpu Tantular Kemranjen Banyumas.

1. Keaktifan siswa kelas XI SMK Mpu Tantular Banyumas yang menerapkan pembelajaran Quantum Teaching lebih tinggi dibandingkan dengan pembelajaran biasa. Sebelum penerapan pembelajaran Quantum Teaching, rata-rata nilai keaktifan siswa sebesar 43,2. Pada siklus I, rata-rata keaktifan siswa meningkat menjadi 56. Setelah dilakukan perbaikan, pada siklus II rata-rata nilai keaktifan siswa meningkat menjadi 79,74. Sehingga sesuai dengan hipotesis awal, yaitu penerapan pembelajaran Quantum Teaching dalam pendidikan agama Buddha dapat meningkatkan keaktifan siswa kelas XI di
SMK Mpu Tantular pada materi aku dan lingkunganku.

2. Pemahaman konsep materi aku dan lingkunganku siswa kelas XI SMK Mpu Tantular Banyumas yang menerapkan pembelajaran Quantum Teaching lebih tinggi dibandingkan dengan pembelajaran yang tidak menerapkan pembelajaran Quantum Teaching. Sebelum penerapan tindakan, rata-rata nilai pemahaman konsep materi siswa sebesar 64,46. Setelah dilakukan tindakan, pada siklus I nilai pemahaman konsep materi siswa meningkat menjadi 75,56. Perbaikan yang dilakukan dengan melaksanakan siklus II menghasilkan nilai rata-rata pemahaman konsep siswa meningkat menjadi 84,46. Sehingga sesuai dengan hipotesis awal, yaitu penerapan pembelajaran Quantum Teaching dalam pendidikan agama Buddha dapat meningkatkan pemahaman konsep materi, siswa kelas XI terhadap materi aku dan lingkunganku di SMK Mpu Tantular.

\section{SARAN}

Berdasarkan kesimpulan tersebut, maka peneliti dapat memberikan saran yang berkaitan dengan penerapan pembelajaran Quantum Teaching sebagai berikut.

1. Bagi guru pendidikan agama Buddha

a. Guru pendidikan agama Buddha dalam melaksanakan pembelajaran diharapkan tidak monoton dan membuat siswa tertarik dengan pembelajaran agama Buddha.

b. Guru pendidikan agama Buddha diiharapkan dapat menggunakan metode pembelajaran Quantum Teaching dalam Standar Kompetensi lainnya. Selain itu, 
pembelajaran Quantum Teaching juga dapat diterapkan pada mata pelajaran lain selain pendidikan agama Buddha. Tujuannya adalah agar kekatifan dan pemahaman konsep materi dapat miningkat.

2. Bagi Kepala Sekolah SMK Mpu Tantular Kemranjen Banyumas, dengan adanya penerapan pembelajaran Quantum Teaching oleh guru mata pelajaran diharapkan pihak sekolah mendukung demi kelancaran pencapaian tujuan pembelajaran.

3. Bagi peneliti selanjutya, diharapkan dapat melakukan penelitian di jenjang pendidikan yang berbeda dan peningkatan aspek yang berbeda. Sehingga pembelajaran Quantum Teaching dapat memberikan dampak aspek kemampuan siswa secara keseluruhan.

\section{DAFTAR PUSTAKA}

Alavaka Sutta, Sutta Nipata. (2003). Penerjemah: Saddatissa. Klaten: Vihara Bodhivamsa.

Anderson, L.W \& Krathwohl, D.R (2010). Kerangka Landasan untuk Pembelajaran, Pengajaran, dan Asesmen. ref.ed. Penerjemah: Agung Prihantoro. Yogyakarta: Pustaka Belajar.

Arikunto, S. (2013). Prosedur Penelitian Suatu Pendekatan Praktik. Jakarta: PT. Rineka Cipta.

Daryanto. (2012). Evaluasi Pendidikan. Jakarta: Rineka Cipta (2011). Penelitian Tindakan Kelas dan Penelitian Tindakan Sekolah Beserta Contoh-contohnya. Yogyakarta: Gava Media.

DePorter, B., dkk (2010). Quantum Teaching Mempraktikkan Quantum Learning di
Ruang-Ruang Kelas. (Alih bahasa: Ary Nilandri). Bandung: Kaifa.

Dimyati \& Mudjiono. (2013). Belajar \& Pembelajaran. Jakarta: Rineka Cipta.

Hanafih, N., dkk. (2012). Konsep Strategi Pembelajaran. Bandung: PT Refika Aditama.

Kusumah, W., \& Dwitagama, D. (2012). Mengenal Penelitian Tindakan Kelas. Jakarta: PT. Indeks.

Majid, A. (2014). Strategi Pembelajaran. Bandung: Remaja Rosdakarya.

Mon, M.T. (2012). The essence of Buddha Abhidhamma. (Alih bahasa: Anthony Lauwrence dan Jenny Wiliani). Jakarta: Manggala Indah.

Mukti, K.W. (2003). Wacana Buddha-Dharma. Jakarta: Yayasan Dharma Pembangunan.

Prastyo,B.Y. \& Fatah, A. (2012). Implementasi Strategi Pembelajaran Quantum Teaching untuk Meningkatkan Minat dan Hasil Belajar dalam Pembelajaran Dasar Otomotif pada Siswa Kelas X Program Keahlian Teknik Mekanik Otomotif SMK Ma'Arif Al-Munawwir. Jurnal Penelitian UNY. Diambil dari http://eprints.uny.ac.id/10386/1/JURNAL. pdf, pada tanggal 24 Desember 2015.

Sa'ud, U.S. (2012). Inovasi Pendidikan. Bandung: Alfabeta.

Silberman, M.L. (2013). Active Learning. Bandung: Nuansa Cendekia.

Slameto. (2010). Belajar \& Faktor-Faktor yang Mempengaruhi. Jakarta: Rineka Cipta.

Sudjana, N. (2012). Penilaian Hasil Proses Belajar Mengajar. Bandung: Remaja Rosdakarya. 
Jurnal Pendidikan, Sains Sosial dan Agama

Sugiyono. (2015). Metode Penelitian Pendidikan.

Bandung: Alfabeta.

Suleman, A.R., Nalole, M., \& Rival, S. (2013).

Upaya Meningkatkan Pemahaman

Konsep Penjumlahan di SDN 3 Tapa

Kabupaten Bone Bolango (Versi

elektronik). Jurnal Skripsi Kualitatif, 1

(1), 5. Diperoleh tanggal 15 Januari 2016,

dari

http://kim.ung.ac.id/index.php/KIMFIP/ar ticle/view/4198/0.

Suprijono, A. (2015). Cooperative Learning. Yogyakarta: Pustaka Pelajar.

Suwandi, S. (2010). Model Assesmen dalam Pembelajaran. Surakarta: Yuma Pustaka.

The Word of The Doctrine, Dhammapada. (2004). Translated: K.R. Norman. Oxford: The Pali Text Society.

Uno, H.B., \& Mohamad, N. (2013). Belajar dengan Pendekatan PAIKEM. Jakarta: Bumi Aksara. 